\title{
PENGGUNAAN EVALUASI MODEL CIPP PADA IMPLEMENTASI KEBIJAKAN PENILAIAN PRESTASI KERJA PEGAWAI NEGERI SIPIL KOTA TANGERANG SELATAN
}

\author{
Erialdy ${ }^{1}$, Sugeng Lubar Prastowo', Ade Indra Permana1 \\ 1Universitas Islam Syekh-Yusuf Tangerang Indonesia \\ Emai: erialdy@unis.ac.id
}

\begin{abstract}
On behalf to produce an excellent service, Civil Servants have to work professionally, certainly through coaching and supervision. Accordingly, the effective assessment method to measure working achievement objectively is required. In this effort, South Tangerang City has issued a policy of South Tangerang City's Mayor Regulation No. 5 of 2018. Policy implementation evaluation used CIPP evaluation model, starts from policy purpose, implementation process to the result of the policy implementation. The research method used is a descriptive qualitative, the research instruments used are observation, interview and documentation study. The analysis of data research uses 4 steps ie. data collection, data reduction, data presentation and conclusion drawing or verification. Data validation testing used is source triangulation techniques. The appraisal of working achievement is used as a basic preparation for the arrangement of reasonable and transparent incentive system, a fair career development and evaluation for to the Local Government of South Tangerang city to its resources.
\end{abstract}

Keywords : Evaluation, Policy Implementation, Working Achievement Appraisal

\begin{abstract}
Abstrak
Untuk menghasilkan pelayanan yang prima, Pegawai Negeri Sipil haruslah bekerja secara profesional, tentu saja melalui pembinaan dan pengawasan maka dibutuhkan metode penilaian yang efektif untuk mengukur prestasi kerja secara objektif. Dalam upaya tersebut, Kota Tangerang Selatan telah menerbitkan kebijakan Peraturan Walikota Tangerang Selatan Nomor 5 Tahun 2018. Evaluasi Implementasi kebijakan menggunakan model evaluasi CIPP mulai dari tujuan kebijakan, proses implementasinya hingga hasil dari implementasi kebijakan tersebut. Metode penelitian kualitatif deskriptif, pengumpulan data menggunakan instrumen penelitian pedoman observasi, wawancara, dan studi dokumentasi. Analisis data penelitian menggunakan empat tahap yaitu pengumpulan data, reduksi data, penyajian data dan penarikan kesimpulan atau verifikasi. Pengujian keabsahan data menggunakan teknik triangulasi sumber. Penilaian prestasi kerja digunakan sebagai dasar bagi penyusunan sistem insentif yang wajar dan transparan, pengembangan karier yang adil serta evaluasi bagi Pemda Kota Tangerang Selatan terhadap sumber daya yang dimiliki.
\end{abstract}

Kata Kunci : Evaluasi, Implementasi Kebijakan, Penilaian Prestasi Kerja

\section{A. PENDAHULUAN}

Evaluasi menurut

Stufflebeam dan Anthony (2017 : 16) adalah "the systematic process of delineating, obtaining, reporting, and applying descriptive and judgmental information about some object's merit, worth, probity, feasibility, safety, significance, and/or equity". evaluasi merupakan proses menggambarkan, memperoleh, dan menyajikan informasi yang berguna untuk merumuskan suatu alternatif keputusan. 
Wandt dan Brown (Anas Sudijono 2009 :1) mendefinisikan evaluation refer to the act or process to determining the value of something. Menurut definisi ini, maka istilah evaluasi itu menunjuk kepada atau mengandung pengertian suatu tindakan atau suatu proses untuk menentukan nilai dari sesuatu.

Pendapat yang tidak jauh berbeda di utarakan Djaali dan Pudji yang di kutip Widodo (2014 : 334) mengartikan evaluasi sebagai proses menilai sesuatu berdasarkan kriteria atau tujuan yang telah ditetapkan yang selanjutnya diikuti dengan pengambilan keputusan atas obyek yang di evaluasi. Dari beberapa teori evaluasi oleh para ahli diatas terdapat persamaan prinsip bahwa evaluasi dilakukan untuk mencari nilai dan kegunaaan dari obyek yang di evaluasi. Kebijakan publik, dilihat dari perspektif instrumental, adalah alat untuk mencapai suatu tujuan yang berkaitan dengan upaya pemerintah mewujudkan nilai-nilai kepublikan (public values).

Dalam tahap inilah aneka rintisan dan tujuan kebijakan yang disusun selama proses perumusan kebijakan dialihkan menjadi program-program (kerja), prosedur, dan regulasi. Implementasi intinya adalah kegiatan untuk mendistribusikan keluaran kebijakan (to deliver policy output) yang dilakukan oleh para implementer kepada kelompok sasaran (target group) sebagai upaya untuk mewujudkan tujuan kebijakan. (Erwan Agus Purwanto dan Dyah
Ratih Sulistyastuti, 2012 : 21)

Implementasi kebijakan publik merupakan proses kegiatan administratif yang dilakukan setelah kebijakan ditetapkan atau disetujui. Kegiatan ini terletak di antara perumusan kebijakan dan evaluasi kebijakan. Implementasi kebijakan mengandung logika yang top-down, maksudnya menurunkan/ menafsirkan alternatif-alternatif yang masih abstrak atau makro menjadi alternatif yang bersifat konkrit atau mikro. (Erwan Agus Purwanto dan Dyah Ratih Sulistyastuti, 2012 : 131)

CIPP adalah model evaluasi yang di dikembangkan oleh Stufflebeam, dkk, CIPP terdiri dari Context evaluation, Input evaluation, Process evaluation dan Product evaluation. Model evaluasi CIPP ini direkomendasikan sebagai kerangka kerja sistematis yang memberi petunjuk kepada pembuat konsep, desain, implementasi, dan penilaian pelayanan dan menyediakan umpan balik, serta penilaian terhadap efektivitas proyek untuk perbaikan selanjutnya (Zhang, Guili, et al, 2011).

Penilaian merupakan suatu proses yang menggambarkan, informasi deskriptif dan bersifat memutuskan tentang kelayakan suatu program dalam rangka memberi masukan bagi pembuatan keputusan.

Menurut Sirait (Agnita Yolanda, dkk. 2015), Penilaian prestasi kerja karyawan dapat dilakukan oleh atasan langsung, yang bertanggung jawab dalam mengevaluasi prestasi bawahannya. Selain itu, atasan 
langsung dianggap lebih memiliki wewenang dan jabatan yang tinggi sehingga dia berhak untuk dapat melakukan penilaian prestasi kerja bawahannya.

Penilaian dapat juga dilakukan oleh sesama rekan kerja, dianggap lebih efektif untuk memprediksi keberhasilan manajemen masa depan.

John M. Owen, (2006) menjelaskan bahwa karyawan memiliki kinerja yang tinggi karena kepuasan terhadap sistem penilaian kinerja yang ada, sehingga meningkatkan motivasi karyawan untuk meningkatkan kinerja mereka yang akan mengarah kepada kesuksesan organisasi dan memberikan kontribusi untuk memotivasi pada karyawan.

Penelitian yang dilakukan oleh Malinda (2014) menunjukkan perlu kejelasan komunikasi yang optimal, dalam pelaksanaan kebijakan yang sesuai dengan desain kebijakan.

Adanya keterbatasan prospek untuk perkembangan karier, umpan balik kinerja yang tidak adekuat, dan mekanisme reward yang rendah (Lutwana, dkk. 2013).

Ochoti (2012), dalam penelitiannya menunjukkan bahwa proses implementasi, hubungan interpersonal, faktor informasi, sikap pekerja, dan ketepatan penilai psikometrik berhubungan positif dengan sistem penilaian kinerja. Jika semua faktor tersebut dipertimbangkan keberadaannya, maka sistem penilaian kinerja tersebut berpotensi menjadi alat manajemen kinerja yang baik

Gambaram di atas menjadi alasan yang kuat untuk dilakukannya penelitian tentang evaluasi implementasi kebijakan penilaian prestasi kerja.

\section{B. Metode}

Penelitian ini menggunakan metode kualitatif deskriftif. Penelitian ini berfokus pada evaluasi implementasi kebijakan Peraturan Walikota Tangerang Selatan Nomor 5 Tahun 2018 tentang Pemberian Tambahan Penghasilan Pegawai Negeri Sipil (PNS) dan Calon Pegawai Negeri Sipil (CPNS) di Lingkungan Pemerintah Kota Tangerang Selatan menggunakan evaluasi model CIPP.

Dengan pemberlakuan kebijakan yang sama kepada setiap Pegawai Negeri Sipil di lingkungan Kota Tangerang Selatan, maka untuk mendapatkan data dalam penelitian ini, peneliti hanya menggunakan sejumlah informan yang dapat mewakili fokus penelitian, berasal dari Badan Kepegawaian, Pendidikan, dan Pelatihan (BKPP), Bagian Hukum Setda Kota Tangerang Selatan, Dinas Kesehatan Kota Tangerang Selatan, UPT Puskesmas di wilayah Kota Tangerang Selatan dan lima orang Pegawai Negeri Sipil (PNS) Tangerang Selatan. Penelitian dilakukan tahun 2018.

Teknik pengumpulan data menggunakan teknik observasi yaitu dengan melakukan kunjungan langsung ke UPT Puskesmas, Dinas 
Kesehatan dan BKPP Kota Tangerang Selatan, wawancara yang dilakukan secara terstruktur maupun tidak terstruktur melalui tatap muka (face to face) maupun dengan menggunakan telepon. Studi dokumentasi diperoleh dari dokumen-dokumen resmi untuk melengkapi data yang diperlukan.

Analisis data penelitian menggunakan empat tahap yaitu pengumpulan data, reduksi data, penyajian data dan penarikan kesimpulan atau verifikasi. Pengujian keabsahan data menggunakan teknik triangulasi sumber.

\section{Temuan Hasil Penelitian}

1. Context Evaluation : Tujuan Kebijakan Penilaian Prestasi Kerja.

Kebijakan yang menjadi dasar penilaian prestasi kerja Pegawai Negeri Sipil di Kota Tangerang Selatan menggunakan Peraturan Pemerintah Nomor 46 Tahun 2011 tentang Penilaian Prestasi Kerja Pegawai Negeri Sipil.

Peraturan Pemerintah tersebut juga menjadi acuan dasar dikeluarkannya Peraturan Walikota Tangerang Selatan Nomor 5 Tahun 2018 tentang Pemberian Tambahan Penghasilan Pegawai Negeri Sipil (PNS) dan Calon Pegawai Negeri Sipil (CPNS) di Lingkungan Pemerintah Kota Tangerang Selatan.

Peraturan Walikota Tangerang Selatan Nomor 5 Tahun 2018 bertujuan untuk meningkatkan kualitas pelayanan publik, kinerja Pegawai Negeri Sipil, disiplin Pegawai Negeri Sipil, dan kesejahteraan Pegawai Negeri Sipil.

Penilaian mencakup tiga aspek yaitu kehadiran, aktivitas harian, dan Penilaian Prestasi Kerja (PPK). Pemerintah daerah Kota Tangerang Selatan ingin membuat penilaian yang lebih spesifik dan detail dalam penilaian prestasi kerja yang ada di lingkungannya.

2. Input Evaluation: Sumber daya yang digunakan.

Banyak Lembaga, Dinas dan instansi terkait sebagai sumber daya yang digunakan untuk melakukan penilaian prestasi kerja Pegawai Negeri Sipil di Kota Tangerang Selatan, tetapi di dalam penelitian ini peneliti hanya berfokus pada BKPP, Dinas Kesehatan dan UPT Puskesmas yang dianggap dapat mewakili Lembaga, Dinas dan Instansi yang lain. a) Badan Kepegawaian, Pendidikan dan Pelatihan (BKPP), dimana salah satu tugas dan fungsinya adalah sebagai pembinaan, pengawasan, pengen dalian, pemantauan pelaksanaan urusan kepegawaian, pendidikan dan pelatihan. b) Dinas Kesehatan. Tugas Kepala Dinas Kesehatan adalah melaksanakan urusan Pemerintah Daerah, dengan fungsinya, yaitu melaksankan pengembangan dan 
peningkatan kompetensi sumber daya kesehatan, serta pelaksanaan pembinaan organisasi profesi Pegawai Negeri Sipil kesehatan sesuai peraturan dan ketentuan yang berlaku. c) Unit Pelaksana Teknis (UPT) Puskesmas. Kepala UPT mempunyai tugas pokok memimpin, mengawasi dan mengkoordinasikan kegiatan penyelenggaraan tugas dan fungsi UPT. Sebagai Kepala Unit Pelaksana Teknis yang merupakan pejabat atasan langsung Pegawai Negeri Sipil melakukan validasi penilaian terhadap implementasi kebijakan, sebelum hasil penilaian tersebut direkapitulasi oleh Badan Kepegawaian, Pendidikan dan Pelatihan (BKPP).

3. Process

Evaluation :

Pelaksanaan Penilaian Prestasi Kerja Pegawai Negeri Sipil.

Proses implementasi kebijakan Walikota Tangerang Selatan mulai diberlakukan pada bulan Januari 2018. Tiga indikator yang dinilai yaitu kehadiran, aktivitas harian, dan Penilaian Prestasi Kerja (PPK), dimana masing-masing aspek tersebut memiliki bobot penilaiannya masing-masing. Kehadiran sebesar $30 \%$, aktivitas harian sebesar $50 \%$ dan Penilaian Prestasi Kerja sebesar $20 \%$.
Aspek pertama yaitu aspek kehadiran dilakukan setiap hari melau kegiatan absensi.

Aktivitas harian merupakan aspek kedua yang dinilai, aktivitas harian tersebut terdiri atas kuantitas dan waktu. yang dimaksud kuantitas berdasarkan volume pekerjaan yang dilaksanakan pada hari dan jam kerja efektif, sedangkan waktu yang adalah hari dan jam kerja efektif yang dihitung selama 330 menit perhari.

Aspek ketiga yaitu Penilaian Prestasi Kerja (PPK) meliputi Sasaran Kerja Pegawai (SKP) dan Perilaku Kerja. Penilaian perilaku kerja terdiri dari beberapa aspek diantaranya orientasi pelayanan, integritas, komitmen, disiplin, kerja sama.

Pejabat penilai adalah atasan langsung PNS yang dinilai dengan ketentuan paling rendah pejabat struktural eselon $\mathrm{V}$ atau pejabat lain yang ditentukan. Oleh karena itu, secara otomatis Kepala Unit Pelaksna Tekhnis (UPT) merupakan atasan langsung yang berhak memberikan penilaian prestasi kerja. Pejabat penilai tersebut wajib melakukan penilaian prestasi kerja yang diinput secara online dengan menggunakan aplikasi penilaian kinerja atau dikenal dengan APIK, terhadap Pegawai Negeri Sipil di lingkungan unit kerjanya 
4. Product Evaluation : HasilHasil Implementasi Kebijakan Penilain Prestasi Kerja

Melalui penilaian prestasi kerja akan diketahui seberapa baik Pegawai Negeri Sipil telah melaksanakan tugas-tugas yang dibebankan kepadanya, sehingga dapat menetapkan penghargaan yang pantas atas prestasi kerja tersebut, bentuk penghargaannya adalah : a) Penghargaan Finansial: berupa Tambahan Penghasilan Pegawai (TPP). Pemberian tambahan penghasilan pada pegawai negeri sipil sebagai salah satu bentuk remunerasi bukan berupa tunjangan kinerja karena untuk hal tersebut membutuhkan analisis jabatan, analisis beban kerja, dan sebagainya, sedangkan untuk Pemerintah Kota Tangerang Selatan masih dalam tahap penyusunan dan penyesuain dengan regulasi yang ada menuju ke penilaian kinerja yang sesungguhnya. Tambahan penghasilan lebih mencerminkan keadilan artinya terlihat perbedaan antara Pegawai Negeri Sipil yang aktif atau yang tidak aktif, terlihatnya dari besaran tambahan penghasilan yang diterima setiap bulan, dapat memotivasi Pegawai Negeri Sipil untuk lebih aktif dalam bekerja. b) Penghargaan Non-Finansial : Diantaranya kesempatan untuk diusulkan mengikuti tugas belajar dan izin belajar. Pemberian tugas belajar dan izin belajar kepada Pegawai Negeri Sipil bertujuan untuk memenuhi kebutuhan Pegawai Negeri Sipil yang memiliki kompetensi dalam melaksanakan tugas melalui peningkatan pengetahuan dan keterampilan, sikap dan perilaku, dan jenjang karier. Hal tersebut diperjelas dengan adanya Peraturan Walikota Tangerang Selatan Nomor 44 Tahun 2016 tentang pemberian tugas belajar dan izin belajar bagi PNS. Persyaratan umum tugas belajar meliputi penilaian prestasi kerja pada dua tahun terakhir bernilai baik.

\section{DISKUSI}

Dengan diberlakukannya otonomi daerah, setiap daerah diberikan kebebasan untuk dapat mengembangkan potensi yang ada di daerahnya, termasuk dalam hal implementasi pnilaian prestasi kerja. Orgamisasi atau lembaga pemerintah daerah memiliki kewenangan dan sumber daya yang dapat mendukung pelaksanaan kebijakan berupa dukungan positif terhadap implementasi kebijakan.

Sistem penilaian prestasi kerja yang adil dan jujur mempunyai pengaruh penting dalam kesuksesan suatu organisasi karena dirasa dapat terhubung dengan penerimaan sistem dengan cepat, kinerja pekerja, dan organisasi (Choi Song Long, dkk. 2013). 
Penelitian lain yang dilakukan oleh Nainggala (2015) menunjukkan bahwa penilaian prestasi kerja berpengaruh terhadap kinerja pekerja dan dapat meningkatkan kinerja pada pekerja. Penilaian prestasi kerja menjadi dasar dalam menentukan kebijakan selanjutnya seperti pengambilan keputusan untuk kenaikan gaji, promosi, pelatihan, pengembangan, dan lain-lain.

Tujuan kebijakan penilaian prestasi kerja Pegawai Negeri Sipil di UPT Puskesmas, secara garis besar disebutkan bertujuan untuk menjamin objektivitas pembinaan Pegawai Negeri Sipil yang dilakukan berdasarkan sistem prestasi kerja dan sistem karier yang dititikberatkan pada sistem prestasi kerja. Adapun untuk penilaian prestasi kerja tersebut berdasarkan prinsip objektif, terukur, akuntabel, partisipatif, dan transparan. Dengan penilaian prestasi kerja tersebut diharapkan dapat memberikan pengaruh positif dan berkontribusi terhadap suatu organisasi dan dapat dijadikan alat yang efektif untuk memperbaiki kinerja dan produktivitas, serta untuk mengembangkan pekerja.

Hasil dari penilaian prestasi kerja digunakan juga untuk keperluan pelatihan, penempatan, penelitian personal, dan pemecatan (Paul M. Muchinsky, 2006).

Penilaian prestasi kerja melibatkan beberapa lembaga pemerintah daerah untuk mendukung pelaksanaan implementasi kebijakan.

Sebagai gambaran hubungan lembaga penilaian prestasi kerja Pegawai Negeri Sipil Kota Tangerang Selatan, pada penelitian ini diwakili oleh UPT Puskesmas, Dinas Kesehatan dan BKPP Kota Tangerang Selatan, seperti yang tergambarkan pada gambar 1, di bawah ini :

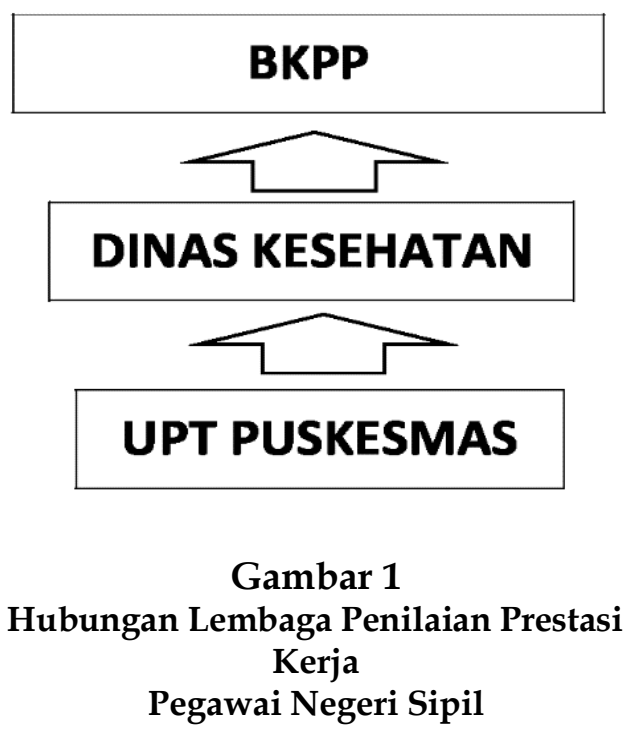

Penilai prestasi kerja (Peraturan Walikota Tangerang Selatan Nomor 33, 2010) adalah Kepala UPT Puskesmas, seorang Kepala yang berada dibawah dan bertanggung jawab kepada Kepala Dinas Kesehatan, memiliki tugas pokok untuk memimpin, mengawasi, dan mengkoordinasikan kegiatan penyelenggaraan tugas dan fungsi UPT Puskesmas yang dilakukan dalam jabatan struktural dan fungsional, bertugas untuk memberikan validasi terhadap laporan yang diinput secara online dengan menggunakan aplikasi penilaian kinerja atau dikenal dengan APIK dan memberikan penilaian terhadap perilaku kerja Pegawai 
Negeri Sipil berdasarkan hasil pengamatannya dengan kriteriakriteria yang sudah ditentukan.

Hasil penilaian yang telah dilakukan oleh UPT Puskesmas, pada setiap akhir bulan diserahkan kepada Dinas Kesehatan sebagai lembaga yang membawahi UPT Puskesmas.

Hasil penilaian prestasi kerja Pegawai Negeri Sipil yang diterima oleh Dinas Kesehatan setelah di verifikasi dilanjutkan hasil penilaian tersebut kepada Badan Kepegawaian, Pendidikan dan Pelatihan (BKPP).

Alur penilaian prestasi kerja Pegawai Negeri Sipil berdasarkan pada kebijakan Peraturan Walikota Tangerang Selatan Nomor 5 Tahun 2018 dapat terlihat pada gambar 2, di bawah ini.

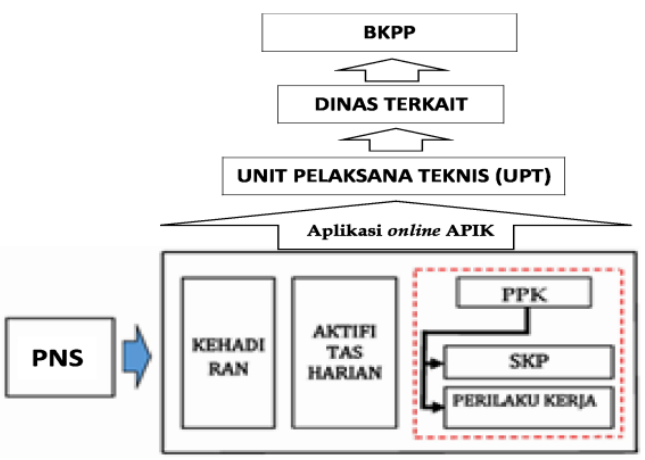

Gambar 2

Alur Penilaian Prestasi Kerja
Pegawai Negeri Sipil

Hasil penilaian prestasi kerja Pegawai Negeri Sipil disamping dapat berpengaruh kepada penghargaan yang didapat berupa peningkatan kesejahteraan dan pengembangan karier, juga dapat berpengaruh pada peningkatan produktifitas kerja.

Reward atau penghargaan adalah suatu bentuk apresiasi yang diberikan kepada seseorang atas dasar prestasi yang telah dicapai.

Hasil dari implementasi kebijakan prestasi kerja Pegawai Negeri Sipil di Kota Tangerang Selatan berupa penghargaan baik berupa finansial maupun non finansial, yaitu a) Pemberian Tambahan Penghasilan (TPP). Besaran tambahan penghasilan yang diterima setiap bulannya berbeda-beda, tergantung pada hasil penilaian. Tambahan penghasilan dapat motivasi Pegawai Negeri Sipil untuk dapat bekerja lebih rajin dan disiplin lagi. b) Kesempatan untuk diusulkan mengikuti tugas belajar dan mendapatkan izin belajar. Tugas belajar merupakan tugas yang diberikan kepada Pegawai Negeri Sipil di lingkungan Pemerintah Kota Tangerang Selatan agar dapat melanjutkan pendidikannya, bertujuan untuk memenuhi kebutuhan Pegawai Negeri Sipil yang mempunyai kompetensi dalam melaksanakan tugas melalui peningkatan pengetahuan dan keterampilan, sikap dan perilaku, dan jenjang karier. Peraturan Walikota Tangerang Selatan Nomor 44 Tahun 2016 Tentang Pemberian Tugas Belajar Dan Izin Belajar Bagi Pegawai Negeri Sipil Pegawai Negeri Sipil, menjelaskan pemberian tugas belajar dan izin belajar dimaksudkan memberi kesempatan dan mendorong Pegawai Negeri Sipil untuk mengembangkan diri, meningkatkan kemampuan dan profesionalisme melalui pendidikan formal dan non formal. 


\section{E. Kesimpulan}

Implementasi kebijakan penilaian prestasi kerja yang didasarkan pada Peraturan Walikota Tangerang Selatan nomor 5 tahun 2018, sudah sesuai dengan arah kebijakan.

Implementasi kebijakan penilaian prestasi kerja sudah menggambarkan objektivitas pembinaan Pegawai Negeri Sipil yang dilakukan berdasarkan sistem prestasi kerja, tercapainya peningkatan produktivitas dan mutu pelayanan Pegawai Negeri Sipil, terwujudnya pengembangan karier bagi Pegawai Negeri Sipil, dan terwujudnya transparansi bagi pelaksanaan pemberian insentif bagi Pegawai Negeri Sipil, baik berupa financial berupa tambahan penghasilan pegawai maupun non financial, yang diantaranya berupa kesempatan untuk mendapatkan izin melanjutkan pendidikan. 


\section{Referensi}

Agnita Yolanda, dkk. (2015). Efectivitas Penilaian Prestasi Kerja Karyawan (Studi Kasus): PTPN IV(Persero)-Kebon Tinjowan Simalungun. Jurna Bismis Administrasi. Vol.4. No.2,

Choi Sang Long, dkk. (2013). A Review on Performance Appraisal System: An Ineffective and Destructive Practice, Middle-East Journal of Scientific Research 14 (7): $887-891$

Daniel L. Stuffbeam and Chris LS Coryn (2014). Evaluation Theory, Models And Aplications, second edition, jossey Bass,

Erwan Agus Purwanto dan Dyah Ratih Sulistyastuti (2012). Implementasi Kebijakan Publik, (Yogyakarta, GavaMedia),

John M. Owen, (2006). Program Evaluation, Form and Approach, Sydney: Allen \& Unwin Pty Ltd,

Lutwana, dkk. (2013). Assesing the implementation of performance management of health care workers in Uganda. BMC Health Service Research, 13 (355), 1-12.

Malinda, (2014). Evaluasi Implementasi Kebijakan Manajemen Sumber Daya Manusia Berbasis Kompetensi di BKKBN.

Ochoti, George Ndemo. (2012). Factors influencing employee performance appraisal system: a case of the ministry of state for provincial administration $\mathcal{E}$ internal.

Paul M. Muchinsky, (2006). Psychology Applied to Work, Eigth Edition

Peraturan Walikota Tangerang Selatan Nomor 44. (2016). Pemberian Tugas Belajar dan Izin Belajar

Peraturan Walikota Tangerang Selatan Nomor 5. (2018). Pemberian Tambahan Penghasilan PNS/CPNS di Lingkungan Pemerintah Kota Tangerang Selatan

Widodo Untung. (2014). Pengaruh kepercayaan pada atasan, komitmen organisasi dan kepuasan kerja terhadap produktivitas karyawan. Fokus Ekonomi, 4(2), 24-39,

Yousaf, dkk. (2014). Impact of financial and non financial rewards on employee motivation. Middle-East Journal of Scientific Research, 21(10), 1776-1786

Zhang, Guili, et al, (2011). Using the context, input, process, and product evaluation model (CIPP) as a comprehensive framework to guide the planning, implementation, and assesment of service-learning programs. Journal of Higher Education Outreach and Engagement, 15(4), 57-8. 